Neurological Sciences

Elsevier Editorial System(tm) for Journal of the

Manuscript Draft

Manuscript Number:

Title: STUDY OF LEUKEMIA INHIBITORY FACTOR POLYMORPHISM WITHIN AN AUSTRALIAN MULTIPLE SCLEROSIS POPULATION

Article Type: Basic Research Paper

Section/Category:

Keywords: Multiple sclerosis; Australia; leukemia inhibitory factor;

polymorphism; restriction fragment length polymorphism; susceptibility.

Corresponding Author: Mr Jason Mackenzie, BBiomedSC

Corresponding Author's Institution: Griffith University

First Author: Jason Mackenzie, BBiomedSC

Order of Authors: Jason Mackenzie, BBiomedSc; Lotti Tajouri; Attila Szvetko; Verena Weth; Julie Moreau; Judith M Greer; Peter A Csurhes; Michael P Pender; Lyn R Griffiths

Manuscript Region of Origin:

Abstract: Objective: To examine a polymorphism within the 3' untranslated region of the Leukemia inhibitory factor gene for an association with multiple sclerosis within an Australian case-control population.

Methods: A test group of 121 unrelated multiple sclerosis patients, of Caucasian origin, and 121 controls, matched for ethnicity, sex and age (+/- 5 years) were included in the study. The LIF 3' UTR StuI polymorphism was genotyped by restriction fragment length polymorphism analysis. Statistical analysis of genotype and allele frequencies included Hardy-Weinberg law and conventional contingency table analysis incorporating the standard chi-squared test for independence.

Results: Allelic and genotype frequencies did not demonstrate a significant association between the case and control groups for the tested LIF 3' UTR StuI polymorphism.

Conclusion: The results indicate that the LIF 3' UTR StuI polymorphism is not associated with multiple sclerosis, however we cannot exclude the hypothesis that other polymorphic alleles of LIF could be implicated in MS susceptibility. 


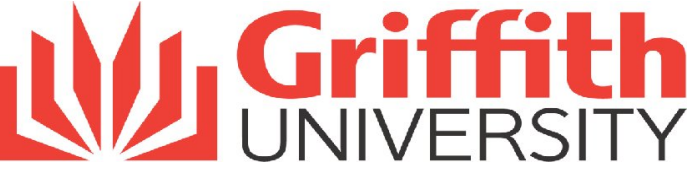

Genomics Research Centre

10 April 2006

Journal Of The Neurological Sciences

Robert P Lisak MD

Department of Neurology

University Health Center, Wayne State University School of Medicine

4201 St.Antoine, Detroit, MI 48201, USA

Dear Dr Lisak,

Please find enclosed a manuscript entitled "Study of Leukemia Inhibitory Factor Polymorphism within an Australian Multiple Sclerosis Population", by Jason Mackenzie, Lotti Tajouri, Attila Szvetko, Verena Weth, Julie Moreau, Judith M. Greer, Peter A. Csurhes, Michael P Pender, and Lyn R Griffiths, for publication submission in the Journal Of The Neurological Sciences.

This manuscript describes an investigation of one polymorphisms, LIF C3951T in Multiple Sclerosis (MS) in a case-control study of an Australian Caucasian population. The MS population was compared with matched controls (gender, age, and ethnicity) using PCR and restriction enzyme techniques. Allele frequencies were compared using Chi-square based statistical analyses. We report that results from the present study do not support a role for the genetic variant in MS susceptibility.

This manuscript has not been nor will be published in whole or in part by any other journal, and all listed authors concur with the submission.

Thank you for taking the time to review this manuscript.

Regards,

Professor Lyn Griffiths

Director, Genomics Research Centre

Head, School of Medical Sciences

Griffith University 
Table 1 Distribution of LIF StuI Variant (genotype and allele) frequencies in MS case and control groups.

\begin{tabular}{|l|c|c|c|c|c|c|}
\hline & \multicolumn{3}{|c|}{ Genotypes* } & & \multicolumn{2}{c|}{ Alleles $^{\#}$} \\
\hline Group & C/C & C/T & T/T & N (genotypes) & C & T \\
\hline MS $^{\text {a }}$ & $50(41 \%)$ & $53(44 \%)$ & $18(15 \%)$ & 121 & $153(63 \%)$ & $89(37 \%)$ \\
\hline RR-MS & $29(44 \%)$ & $25(38 \%)$ & $12(18 \%)$ & 66 & $83(63 \%)$ & $49(37 \%)$ \\
\hline SP-MS & $12(40 \%)$ & $17(57 \%)$ & $1(3 \%)$ & 30 & $41(68 \%)$ & $19(32 \%)$ \\
\hline PP-MS & $9(36 \%)$ & $11(44 \%)$ & $5(20 \%)$ & 25 & $29(58 \%)$ & $21(42 \%)$ \\
\hline Control & $52(43 \%)$ & $55(45 \%)$ & $14(12 \%)$ & 121 & $159(66 \%)$ & $83(34 \%)$ \\
\hline
\end{tabular}

*genotype distribution comparison for total MS $\left(\chi^{2}=0.58, \mathrm{P}=0.75\right)$,

${ }^{\#}$ allele distribution comparison for total MS $\left(\chi^{2}=0.32, \mathrm{P}=0.57\right)$

${ }^{\mathrm{a}}$ Hardy-Weinberg equilibrium $\mathrm{P}=0.52$

${ }^{\mathrm{b}}$ Hardy-Weinberg equilibrium $\mathrm{P}=0.92$ 


\section{STUDY OF LEUKEMIA INHIBITORY FACTOR POLYMORPHISM WITHIN AN AUSTRALIAN MULTIPLE SCLEROSIS POPULATION}

Jason Mackenzie ${ }^{1}$, Lotti Tajouri ${ }^{1}$, Attila Szvetko ${ }^{1}$, Verena Weth ${ }^{1}$, Julie Moreau ${ }^{1}$, Judith M. Greer ${ }^{2}$, Peter A.Csurhes ${ }^{2}$, Michael P. Pender ${ }^{2}$ and Lyn R. Griffiths ${ }^{1 *}$

${ }^{1}$ Genomics Research Centre, School of Health Medical Science, Griffith University Gold Coast, Southport, Queensland, Australia 4215

${ }^{2}$ Neuroimmunology Research Centre, School of Medicine, University of Queensland; and Department of Neurology, Royal Brisbane and Women's Hospital, Herston, Brisbane, Queensland, Australia 4029

E.mail: Prof Lyn Griffiths (1.griffths@griffith.edu.au)

*Correspondence to Lyn Griffiths, Genomics Research Centre, School of Medical Science, Griffith University Gold Coast, Southport, Queensland, Australia 4215

The research undertaken in this article complies with the Australian ethics standards and was approved by the Griffith University Ethics Committee. 
Introduction

Multiple sclerosis (MS) is a central nervous system (CNS) disease and is associated with the formation of demyelinated plaques. These plaques are the result of an ongoing infiltration of leukocytes in the CNS parenchyma causing damage to the axonal insulator, myelin. Demyelination leads to alteration of the action potential conduction along axons and results in broad and various symptoms [1]. The pathology of MS is classified into three clinical types: relapsing-remitting MS (RR-MS), secondary progressive MS (SP-MS) and primary progressive MS (PP-MS). Interestingly, RR-MS coincides with periods of remission, in which regeneration of the myelin is known to involve anti-inflammatory agents, neurotrophins and resident precursors of oligodendrocytes [1].

Particular attention has been focused on the investigation of inflammatory molecules within the immune system. In the presence of myelin proteins, infiltrated leukocytes become reactive and secrete a plethora of pro-inflammatory agents degrading the myelin sheath [2]. All genome-wide screens in MS have revealed a global implication of the major histocompatibility complex (MHC) at the 6p21 chromosomal region [37]. Leukemia inhibitory factor (LIF) belongs to the neurotrophic family and is present in MS plaques [8]. The gene coding for LIF is located at 22q12.2, a region associated with MS in a Spanish population [9]. Macrophages and T cells secrete LIF and have been shown to confer oligodendrocyte protection in the CNS [8]. Experiments undertaken in the experimental allergic encephalomyelitis animal model of MS have shown that the level of expression of LIF mRNA is up-regulated in plaques [10]. Additionally, antibodies directly targeted to LIF and inhibiting LIF action showed increase severity in EAE mice [11]. The positive effect on oligodendrocytes appears 
to be mediated through LIF induced activation of suppressors of cytokine signalling (SOCS) [12]. SOCS have critical roles in regulating numerous cytokines that act through the janus kinase/signal transducer and activator of transcription (JAK/STAT) pathway, creating a negative feedback loop that limits the effect of cytokine signalling on the cell [13]. The up-regulation of SOCS has been shown to ameliorate arthritis in mice, and possibly be a therapeutic strategy for treating the inflammatory disease $[14,15]$. SOCS regulates an important cytokine interferon- $\gamma$ (INF $\gamma)$ which is widely implicated in MS lesions [16,17]. In addition, LIF has opposite effects to the proinflammatory agent INF $\gamma$ and has been demonstrated to block the cytotoxic effects of INF $\gamma$ on oligodendrocytes [18].

Interestingly, a polymorphism located within the $3^{\prime}$ untranslated region (UTR) of LIF has been shown to affect the level of stability of LIF mRNA [19]. This $C \rightarrow T$ transition reduces stability of LIF mRNA and may potentially reduce the expression of LIF [19]. In this present report, we investigated the genotypes of an Australian MS population $(\mathrm{n}=121)$ age and sex matched with non neurological disease affected healthy controls $(n=121)$ for the $C \rightarrow T$ transition polymorphism of the LIF gene. 


\section{Methods}

Subject Groups. The study used unrelated participants of Caucasian (Northern European) origin. The study protocol was approved by Griffith University's Ethics Committee for Experimentation on Humans. The test groups consisted of $121 \mathrm{MS}$ patients and 121 controls, matched for ethnicity, sex and age (+/- 5 years). The MS population was obtained from patients from the Multiple Sclerosis Clinic at the Royal Brisbane and Women's Hospital, from the South East Queensland region. This case group consisted of $75 \%$ women and $25 \%$ men and were categorised into three groups according to the clinical course: RR-MS, SP-MS and PP-MS with frequencies of $55 \%, 25 \%$, and $20 \%$, respectively. MS diagnosis of all patients was per the 2005 revised McDonald criteria [1]. The control group was also obtained from the South East Queensland region through the Genomics Research Centre, Southport, with each control matched to an MS patient for the variables age (+/- 5 years), sex, and ethnicity. All individuals gave informed consent before participating in the research. Genomic DNA was extracted from peripheral blood leucocytes using a standard salting-out protocol as previously described [20].

Genotyping. The $\mathrm{C} \rightarrow \mathrm{T}$ polymorphism was genotyped with a restriction fragment length polymorphism (RFLP) used to detect each variant. The 3' UTR of LIF was investigated using the StuI restriction enzyme to detect, at the nucleotide position 3951, a $\mathrm{C}$ to $\mathrm{T}$ transition. The polymorphic region was amplified by standard, unlabeled oligonucleotides followed by restriction enzyme digestion corresponding to the RFLP. Oligonucleotide primers used for the StuI RFLP were: forward primer 5'AGGGGCAGGTTGCTAAGTCAG-3'; reverse 5'-CCCCATTCTCTCAGATCCGA- 
3'. For detection of the LIF marker, 20-30 ng genomic DNA was amplified with $1 \mathrm{X}$ polymerase chain reaction (PCR) buffer, $2.5 \mathrm{mM} \mathrm{MgCl} 2,0.2 \mathrm{mM}$ each $\mathrm{dNTP}, 0.2 \mu \mathrm{M}$ each primer and $\mathrm{Taq}$ polymerase in a $25-\mu \mathrm{L}$ final volume on a Corbett (Sydney, Australia) PC-960 thermocycler. Cycles consisted of a 4-min denaturation at $95^{\circ} \mathrm{C}$ followed by 40 cycles of $95^{\circ} \mathrm{C}$ for 30 seconds and $59^{\circ} \mathrm{C}$ for 30 seconds and $72^{\circ} \mathrm{C}$ for 30 seconds with a final extension at $72^{\circ} \mathrm{C}$ for $5 \mathrm{~min}$. PCR products were digested with StuI $\left(1 \mathrm{U}\right.$ at $\left.37^{\circ} \mathrm{C}\right)$ and electrophoresed on $2 \%$ ethidium bromide stained agarose gels. Genotypes were denoted as TT (488 bp), TC (488, 124, 364 bp) or CC $(364,124 b p)$.

Statistical analysis. Genotype and allele frequencies for the LIF variants were calculated from observed genotype counts. As a statistical control for systematic genotyping error and population stratification, the expected genotype proportions according to the Hardy-Weinberg law were calculated and compared to observed genotypes. Genotype and allele frequencies were initially assessed for association with MS using conventional contingency table analyses incorporating the standard chi-squared test for independence. This analysis produces a $\chi^{2}$ statistic with one or two degrees of freedom and corresponding P-values for allele and genotype distributions, respectively. 


\section{Results}

We could clearly determine the type of LIF StuI polymorphism in all patients and controls. The proportion of the three LIF StuI genotypes, denoted as TT (488 bp), TC $(488,124,364 \mathrm{bp})$ or $\mathrm{CC}(364,124 \mathrm{bp})$, are tabulated in Table 1 . The expected genotype proportions were according to Hardy-Weinberg equilibrium for patient and control cohorts (MS P $=0.52$, Control $\mathrm{P}=0.92$ ). Analysis was conducted by the $2 \times 3$ chi-square test for patient and control groups genotype frequency with results indicating no statistically significant association $\left(\chi^{2}=0.58, \mathrm{P}=0.75\right)$. Similar analysis by $2 \times 2$ chi-square test was conducted for patient and control groups allele frequency with results showing no statistically significant association $\left(\chi^{2}=0.32, \mathrm{P}=\right.$ 0.57). In addition, no significant association was shown with any of the patient subtypes compared to control allele or genotype frequencies $(\mathrm{P}>0.05)$. 
Discussion:

The aim of this study was to investigate a C/T polymorphism in the LIF gene for its involvement in MS susceptibility within an Australian cohort. The polymorphism investigated was distinguishable by StuI restriction enzyme digest and genotyped in 121 MS Australian individuals and 121 matched controls. A StuI restriction site is located within the $3^{\prime}$ UTR of LIF. Our results showed no significant association between cases and controls for the tested LIF 3' UTR StuI polymorphism.

During CNS inflammation, LIF is secreted by astrocytes [22] and acts on oligodendrocytes to prevent their loss and increase their survival [23,24]. Furthermore, protective effects of LIF include roles in reducing cytotoxic activity of INF $\gamma$, a pro-inflammatory molecule secreted by infiltrating T cells. Additionally, the Th1 to Th2 shift observed in MS remissions correlates with differences in LIF secretion levels between these types of cells [8]. Th2 cells show higher LIF concentrations compared to Th1 clones demonstrating a LIF Th2 mediated antiinflammatory effect. However, LIF neurotrophin has been shown to be reduced in RR-MS compared to controls [8]. Interestingly, Simvastatin, a cholesterol lowering drug with associated anti-inflammatory effects that may possibly be used in the future to treat MS [25], has previously been shown to increase LIF level secretions from both CD4+ and CD8+ T cells [8]. Despite results implicating a role for LIF in MS, our study could not demonstrate any association between the tested LIF functional variant and MS. Similarly, results of a recent Belgium study also showed no association for the $\mathrm{C} \rightarrow \mathrm{T}$ transition of LIF in MS [21]. We cannot however exclude 
the hypothesis that other polymorphic alleles of LIF could be implicated in MS susceptibility.

LIF acts on the LIF receptor (LIFR), a gene localised to 5p13, a region strongly associated with MS especially in Finnish populations [26]. Of note, recent studies from UK, Scandinavia, Belgium and USA revealed that interleukin 7 receptor alpha (IL7RA) also localised to 5p13 might be implicated in MS [21,27,28]. Association studies for LIFR have not yet been carried out and may be useful for determining whether LIFR plays a role in MS susceptibility. 
Acknowledgements:

The research was supported by Griffith University, with Lotti Tajouri supported by a Griffith University Postdoctoral Fellowship and Attila Szvetko by a Trish Foundation MS Scholarship. 
Reference:

1. Frohman E, Racke M, Raine C. Multiple sclerosis - the plaque and its pathogenesis. N Engl J Med 2006;354(9):942-55.

2. Steinman L. Multiple sclerosis: a two stage disease. Nat Immunol 2001;2:76265 .

3. Ebers G, Kukay K, Bulman D, Sadovnick A, Rice G, Anderson C, Armstrong H, Cousin K, Bell R, Hader W, Paty D, Hashimoto S, Oger J, Duguette P, Warren S, Gray T, O'Connor P, Nath A, Auty A, Metz L, Francis G, Paulseth J, Murray T, Pryse-Phillips W, Nelson R, Freedman M, Brunet D, Bouchard J, Hinds D, Risch N. A full genome search in multiple sclerosis - the plaque and its pathogenesis. Nat Genet 1996;13(4):472-76.

4. Haines J, Ter-Minassian M, Bazyk A, Gusella J, Kim D, Terwedow M, PericakVance M, Rimmler J, Haynes C, Roses A, Lee A, Shaner B, Menold M, Seboun E, Fitoussi R-P, Gartioux C, Reyes C, Ribierre F, Gyapay G, Weissenbach J, Hauser S, Goodkin D, Lincoln R, Usuku K, Garcia-Merino A, Gatto N, Young S, Oksenberg J. A complete genomic screen for multiple sclerosis underscores a role for the major histocompatibility complex. Nat Genet 1996;13(4):469-71.

5. Sawcer S, Jones H, Feakes R, Gray J, Smaldon N, Chataway J, Robertson N, Clayton D, Goodfellow P, Compston A. A genome screen in multiple sclerosis reveals susceptibility loci on chromosome 6p21 and 17q22. Nat Genet 1996;13(4):464-68.

6. Kuokkanen S, Gschwend M, Rioux J, Daly M, Terwilliger J, Tienari P, Wikström J, Palo J, Stein L, Hudson T, Lander E, Peltonen L. Genomewide scan of multiple sclerosis in Finnish multiplex families. Am J Hum Genet 1997;61(6):1379-87.

7. Hafler D, Compston A, Sawcer S, Lander E, Daly M, De Jager P, de Bakker P, Gabriel S, Mirel D, Ivinson A, Pericak-Vance M, Gregory S, Rioux J, McCauley J, Haines J, Barcellos L, Cree B, Oksenberg J, Hauser S. Risk alleles for multiple sclerosis identified by a genomewide study. N Engl J Med 2006;357(9):851-62.

8. Vanderlocht J, Hellings N, Hendriks JJ, Vandenabeele F, Moreels M, Buntinx M, Hoekstra D, Antel JP, Stinissen P. Leukemia inhibitory factor is produced by myelin-reactive $\mathrm{T}$ cells from multiple sclerosis patients and protects against tumor necrosis factor-alpha-induced oligodendrocyte apoptosis. J Neurosci Res 2006;83(5):763-74.

9. Goertsches R, Villoslada P, Comabella M, Montalban X, Navarro A, de la Concha EG, Arroyo R, Lopez de Munain A, Otaegui D, Palacios R, Perez-Tur J, Jonasdottir A, Benediktsson K, Fossdal R, Sawcer S, Setakis E, Compston A; Spanish MS Genetics Group. A genomic screen of Spanish multiple 
sclerosis patients reveals multiple loci associated with the disease. J Neuroimmunol 2003;143(1-2):124-8.

10. Butzkueven H, Zhang J, Soilu-Hanninen M, Hochrein H, Chionh F, Shipham K, Emery B, Turnley A, Petratos S, Ernst M, Bartlett P, Kilpatrick T. LIF receptor signalling limits immune-mediated demyelination by enhancing oligodendrocyte survival. Nat Med 2002;8(6):613-19.

11. Butzkueven H, Emery B, Cipriani T, Marriott MP, Kilpatrick TJ. Endogenous leukemia inhibitory factor production limits autoimmune demyelination and oligodendrocyte loss. Glia 2006;53(7):696-703.

12. Naka T, Narazaki M, Hirata M, Matsumoto T, Minamoto S, Aono A, Nishimoto N, Kajita T, Taga T, Yoshizaki K, Akira S, Kishimoto T. Structure and function of a new STAT-induced STAT inhibitor. Nature 1997;387(6636):924-9.

13. Alexander W, Hilton D. The role of suppressors of cytokine signalling (SOCS) proteins in regulation of the immune response. Ann Rev Immunol 2004;22:503-29.

14. Egan P, Lawlor K, Alexander W, Wicks I. Supressor of cytokine signalling-1 regulates acute inflammatory arthritis and $\mathrm{T}$ cell activation. J Clin Invest 2003;111(6):915-24.

15. Rahman A. Regulators of cytokine signalling in rheumatoid arthritis. Rheumatology 2007;46:1745-46.

16. Alexander W, Starr R, Fenner J, Scott C, Handman E, Sprigg N, Corbin J, Cornish A, Darwiche R, Owczarek C, Kay T, Nicola N, Hertzog P, Metcalf D, Hilton D. SOCS1 is a critical inhibitor of Interferon $\gamma$ signalling and prevents the potentially fatal neonatal actions of this cytokine. Cell 1999;98(5):597608.

17. Vartanian T, Li Y, Zhao M, Stefansson K. Interferon- $\gamma$-induced oligodendrocyte cell death: implications for the pathogenesis of multiple sclerosis. Mol Med 1995;1(7):732-43.

18. Emery B, Butzkueven H, Snell C, Binder M, Kilpatrick TJ. Oligodendrocytes exhibit selective expression of suppressor of cytokine signaling genes and signal transducer and activator of transcription 1 independent inhibition of interferon-gamma-induced toxicity in response to leukemia inhibitory factor. Neuroscience 2006;137(2):463-72.

19. Ishida R, Ezura Y, Iwasaki H, Nakazawa I, Kajita M, Kodaira M, Ito H, Emi M. Linkage disequilibrium and haplotype analysis among four novel singlenucleotide polymorphisms in the human leukemia inhibitory factor (LIF) gene. J Hum Genet 2001;46(10):557-9. 
20. Polman C, Reingold S, Edan G, Filippi M, Hartung H, Kappos L, Lublin F, Metz L, McFarland H, O’Connor P, Sandberg-Wollheim M, Thompson A, Weinshenker B, Wolinsky J. Diagnostic criteria for multiple sclerosis: 2005 revisions to the "McDonald criteria". Ann Neurol 2005;58:840-6.

21. Tajouri L, Ovacaric M, Curtain R, Lea R, Johnson M, Csurhes P, Pender M, Griffiths L. Allelic variation in the vitamin D receptor gene is associated with multiple sclerosis in an Australian population. J Neurogenet 2005;19(1):25-38.

22. Banner LR, Moayeri NN, Patterson PH. Leukemia inhibitory factor is expressed in astrocytes following cortical brain injury. Exp Neurol 1997;147:1-9.

23. Mayer M, Bhakoo K, Noble M. Ciliary neurotrophic factor and leukemia inhibitory factor promote the generation, maturation and survival of oligodendrocytes in vitro. Development 1994;120:143-153.

24. Butzkueven H, Zhang J, Soilu-Hanninen M, Hochrein H, Chionh F, Shipham K, Emery B, Turnley A, Petratos S, Ernst M, Bartlett P, Kilpatrick T. LIF receptor signaling limits immunemediated demyelination by enhancing oligodendrocyte survival. Nat Med 2002;8:613-619.

25. Neuhaus O, Stuve O, Archelos J, Hartung H. Putative mechanisms of action of statins in multiple sclerosis - comparison to interferon-beta and glatiramer acetate. J Neurol Sci 2005;233(1-2):173-77.

26. Vanderlocht J, Burzykowski T, Somers V, Stinissen P, Hellings N. No association of leukemia inhibitory factor (LIF) DNA polymorphisms with multiple sclerosis. J Neuroimmunol 2006;171(1-2):189-92.

27. Kuokkanen S, Sundvall M, Terwilliger J, Tienari P, Wikström J, Holmdahl R, Petterson U, Peltonen L. A putative vulnerability locus to multiple sclerosis maps to 5p14-p12 in region syntenic to the murine locus Eae2. Nat Genet 1996;13(4):477-80.

28. Gregory SG, Schmidt S, Seth P, Oksenberg JR, Hart J, Prokop A, Caillier SJ, Ban M, Goris A, Barcellos LF, Lincoln R, McCauley JL, Sawcer SJ, Compston DA, Dubois B, Hauser SL, Garcia-Blanco MA, Pericak-Vance MA, Haines JL; Multiple Sclerosis Genetics Group. Interleukin 7 receptor alpha chain (IL7R) shows allelic and functional association with multiple sclerosis. Nat Genet 2007;39(9):1083-91.

29. Lundmark F, Duvefelt K, Iacobaeus E, Kockum I, Wallström E, Khademi M, Oturai A, Ryder LP, Saarela J, Harbo HF, Celius EG, Salter H, Olsson T, Hillert J. Variation in interleukin 7 receptor alpha chain (IL7R) influences risk of multiple sclerosis. Nat Genet 2007;39(9):1108-13. 